\title{
Programa Tutorial Acadêmico no Curso de Enfermagem: o aluno como sujeito do cuidado
}

As políticas públicas definidas para a educação na área de saúde, fundamentadas na Lei de Diretrizes e Bases da Educação Nacional (LDB), nas Diretrizes Curriculares Nacionais (DCN), no Sistema Único de Saúde (SUS), precisam ser consolidadas e legitimadas. Para que tal ocorra, é indispensável o implemento do Projeto Político-Pedagógico (PPP). Entendendo-se Projeto Político Pedagógico como uma forma de explicitar os objetivos do curso e orientar as estratégias a serem utilizadas. Desse modo, há necessidade de os cursos investirem na construção de práticas com o objetivo de atender as suas metas e possibilitar a incorporação de novas necessidades. Percebe-se na maioria dos cursos de enfermagem uma lacuna a respeito do atendimento ao aluno, portanto, é importante que neste espaço seja construído um trabalho amplo de instrumentalização não só com os universitários ingressantes, mas também com os veteranos, para que possam assistir a clientela nas mais diferentes situações. Pensando assim, é importante que os cursos utilizem estratégias que propiciem aos alunos conhecimento de seus sentimentos, emoções, fragilidades e potencialidades como questões que devem ser fortalecidas na sua formação para que possam cuidar do cliente sob sua responsabilidade.

Nessa linha de raciocínio, uma das metas de expansão que os cursos de enfermagem podem construir é o Programa Tutorial Acadêmico (PTA). Por quê? Porque este programa poderá ajudar o aluno a se integrar na vida acadêmica por meio da orientação de um professor que o auxiliará a planejar ações que facilitem o seu desempenho acadêmico na Universidade.

Quem poderá fazer isso? O professor-tutor, este deve ser o docente que ministra a disciplina Introdução à Enfermagem, cabendo a ele a responsabilidade pelo planejamento e a execução das atividades que venham a melhorar o desempenho acadêmico e pelo encaminhamento de problemas específicos de ajustamento do universitário, uma vez que a maioria dos alunos ingressantes nas universidades atualmente está na faixa etária de 18 anos e vêm de outras cidades. Também ajudar na integração e na situação de exclusão vivenciada pelos alunos no cotidiano do curso. Consideramos esses problemas como necessidades básicas, que podem se exteriorizar por meio de uma simples falta de adaptação até verdadeiros transtornos emocionais que podem se apresentar de forma latente ou manifesta que reclamam providências. Deve-se considerar o Programa Tutorial Acadêmico como um espaço privilegiado para o atendimento ao aluno no que diz respeito às tarefas cotidianas e terapêuticas e este deve ter como proposta trabalhar dimensões como a da subjetividade, da afetividade, dimensões estas pouco lembradas na relação aluno-professor.

Vale dizer ainda que é importante que cada um de nós realize nossas próprias transformações, investindo em terapias visando a melhorar o relacionamento interpessoal e a comunicação para uma melhor integração com os outros e principalmente com o aluno. Se assim trabalharmos significa que estamos tentando proporcionar ao aluno unir a competência técnica à competência emocional. Dessa maneira, auxiliaremos na consolidação do Projeto Político Pedagógico que é o de formar profissionais críticos, reflexivos, com competência técnico-científica, ético-política e socioeducacional e com capacidade para manter relações intra e interpessoais efetivas, cuidando da coletividade com qualidade, considerando o quadro epidemiológico da região e do País.

Prof $^{a}$ Dra Francisca Lucélia Ribeiro de Farias Universidade de Fortaleza - UNIFOR 


\section{Academic tutorial program in nursing: the student as object of care}

The public policies defined for education in the area of Health, based on the Lei de Diretrizes $e$ Bases da Educação Nacional (LDB), on the Diretrizes Curriculares Nacionais (DCN) and on the Sistema Único de Saúde (SUS), must be consolidated and legitimated. In order for that to happen, the implementation of the Projeto Politico-Pedagógico, or Political-Pedagogical Project (PPP), is indispensable - the PPP being understood as a way of presenting explicitly the objective of the course and of orienting the strategies that are to be used in order to attain it. It is thus necessary for the courses to invest on the establishment of practices that have the aim of reaching their goals and of making possible the incorporation of new needs. In the majority of Nursing courses there can be seen a gap regarding the attention given to the student. It is important, therefore, to build in this space a wideranging work of instrumentation, not only with newly admitted students, but with veteran students as well, so that in the future they will be able to assist their clientele in situations as varied as possible. With this perspective, it is important that the courses use strategies that enable students to get to know their feelings, emotions, shortcomings and potentialities as questions that must be strengthened in their formation so that later they are able to care for the client that is under his/her responsibility.

Thinking along these lines, one of the goals for expansion that Nursing courses can develop is the Programa Tutorial Acadêmico - Academic Tutorial Program - (PTA). Why? Because this program may be useful for the student to integrate himself/herself in academic life through the orientation of a professor who will help him/her to plan actions that will make easier his/her academic performance in the University.

Who can do that? The tutor-professor can. He/she must be the professor who teaches the discipline Introduction to Nursing. It is his/her responsibility the planning and the execution of the activities that may improve the student's academic performance, as well as addressing his/her specific problems of adjustment, since the age of the majority of the students now entering the university is around 18 - and most of them come from other cities. The professor is also supposed to help in the integration of the students and to give support in the situation of exclusion experienced by many of them in the course's daily routine. We consider those problems basic necessities, which at times are expressed as a mere difficulty in adapting, but can also become a true emotional disturbance that may appear in a latent or manifest form and requires action. The Academic Tutorial Program should be considered a privileged space for the attention to the student with respect to daily and therapeutic tasks, and should have as its goal to work with dimensions such as subjectivity and feelings, which are seldom part of studentprofessor relations.

It is also worth pointing out how important it is that each one of us makes his/her own transformations, investing in therapies aimed at improving interpersonal relations and communications in order to take further our integration with others, particularly with students. Such attitude means that we are trying to offer to the student the possibility of combining technical and emotional competence. By doing so we will help the consolidation of the Political-Pedagogical Process, which seeks to form professionals that are critical and reflexive, have technical-scientific, ethical-political and socioeducational competence, and are capable of establishing effective intra and inter-personal relations, of providing care for the collectivity with quality and of taking into consideration the epidemiological situation of the region and of the country. 


\section{Programa de tutoría acadêmica en el curso de pre grado en enfermería: el alumno como sujeto del cuidado}

Las políticas públicas definidas para la educación en el área de la salud, fundamentadas en la Ley de Directrices y Bases de la Educación Nacional (LDB), en las Directrices Curriculares Nacionales $(D C N)$, en el Sistema Único de Salud (SUS), precisan ser consolidadas y legitimadas. Para que eso ocurra, es indispensable la implementación del Proyecto Político-Pedagógico (PPP). Entendiéndose como Proyecto Político Pedagógico una forma de explicitar los objetivos del curso y orientar las estrategias a ser utilizadas. De ese modo, hay necesidad de que los cursos inviertan en la construcción de prácticas con el objetivo de atender a sus metas y posibilitar la incorporación de nuevas necesidades. Se percibe en la mayoría de los cursos de pre grado en enfermería una laguna respecto a la atención del alumno, por tanto, es importante que en este espacio se construya un trabajo amplio de instrumentación no sólo con los universitarios que recién han ingresado, sino también con los veteranos, para que puedan asistir a la clientela en las más variadas situaciones. Pensando así, es importante que los cursos utilicen estrategias que propicien en los alumnos conocimiento de sus sentimientos, emociones, fragilidades y potencialidades como cuestiones que deben ser fortalecidas en su formación para que puedan cuidar del cliente bajo su responsabilidad.

En esa línea de raciocinio, una de las metas de expansión que los cursos de pre grado en enfermería pueden construir es el Programa de Tutoría Académica (PTA). Por qué? Porque este programa podrá ayudar al aluno a integrarse en la vida académica por medio de la orientación de un profesor que lo auxilie en la planificación de acciones que faciliten su desempeño académico en la Universidad.

Quién podrá hacer eso? El profesor-tutor, debe ser el docente que administra la disciplina Introducción a la Enfermería, cabiéndole la responsabilidad por la planificación y la ejecución de las actividades que ayuden a mejorar el desempeño académico y por el encaminamiento de problemas específicos de ajuste del universitario, dado que la mayoría de los alumnos ingresantes en las universidades actualmente está en el grupo etáreo de 18 años y vienen de otras ciudades. También ayudar en la integración y en la situación de exclusión vivenciada por los alumnos en el cotidiano del curso. Consideramos esos problemas como necesidades básicas, que pueden exteriorizarse por medio de una simple falta de adaptación hasta verdaderos trastornos emocionales que pueden presentarse de forma latente o manifiesta que reclaman la toma de providencias. Se debe considerar el Programa de Tutoría Académica como un espacio privilegiado para la atención al alumno en lo que respecta a las tareas cotidianas y terapéuticas y éste debe tener como propuesta trabajar dimensiones como el de la subjetividad y la afectividad, que son poco recordadas en la relación alumno-profesor.

Vale decir aún que es importante que cada uno de nosotros realicemos nuestras propias transformaciones, invirtiendo en terapias visando mejorar la relación interpersonal y la comunicación para favorecer la integración con los otros y principalmente con el alumno. Si trabajamos así significa que estamos intentando proporcionar al alumno la posibilidad de unir la competencia técnica a la competencia emocional. De esta manera, estaremos auxiliando en la consolidación del Proyecto Político Pedagógico que es el de formar profesionales críticos, reflexivos, con competencia técnicocientífica, ético-política y socioeducacional y con capacidad para mantener relaciones intra e interpersonales efectivas, cuidando de la colectividad con calidad, considerando el cuadro epidemiológico de la región y del País. 